\title{
Application of Modern Techniques in Animal Production Sector for Human and Animal Welfare
}

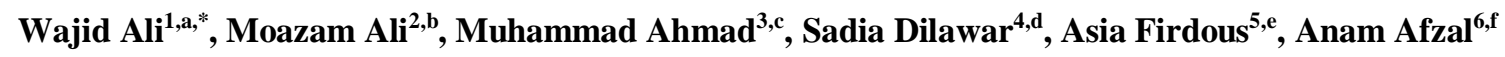 \\ ${ }^{I}$ Department of Animal Production and Technologies, Faculty of Agricultural Sciences and Technologies, Nigde Omer Halisdemir \\ University, Turkey \\ ${ }^{2}$ Department of clinical medicine and surgery, University of Agriculture Faisalabad, Pakistan \\ ${ }^{3}$ Department of clinical medicine and surgery, Faculty of veterinary sciences, University of Veterinary and Animal Sciences, Lahore, \\ Pakistan \\ ${ }^{4}$ Department of livestock production, Faculty of Veterinary Sciences, Bahauddin Zakariya University, Multan, Pakistan \\ ${ }^{5}$ Department of Theriogeniology, Faculty of veterinary sciences, University of Veterinary and Animal Sciences, Lahore, Pakistan. \\ ${ }^{6}$ Department of microbiology, Faculty of veterinary sciences, University of Veterinary and Animal Sciences, Lahore, Pakistan.
}

*Corresponding author

\begin{tabular}{l|l}
\hline A R T I C L E I N F O & A B S T R A C T \\
\hline Review Article & $\begin{array}{l}\text { In this epoch, the tremendous increase in the world population accounts for the continuous supply of } \\
\text { foodstuff. According to the FAO report, the global population is probable to cross the 9 billion in } 2050 . \\
\text { With constant population pressure, we are going to face the challenges of food shortage globally about } \\
\text { agriculture. The animal production field provides a major share in the supply of foodstuff to compensate } \\
\text { for the stress of food scarcity. By adopting the advanced technologies in the animal production field, its } \\
\text { productivity can enhance significantly. Innovation in technology has made work easier with the } \\
\text { development of different software and the internet. Technologic development made farmers work more } \\
\text { contentedly hence, ultimately amplifying the animal production, proficiency, profitability as well as } \\
\text { providing a prompt way for livestock sustainability. The animal production consists mainly of } 8 \text { factors } \\
\text { including 3 major (animal breeding and genetics, animal nutrition, and reproductive performances) and } 5 \\
\text { Accepted : } 28 / 12 / 2019 \\
\text { minor (health observation, farm management, water, manure, machinery, environment control, milking } \\
\text { automation and electronic identification). The use of advanced technologies in these sectors is found to be } \\
\text { fluent by intensifying the ratio of sustainable livestock farming and the welfare of mankind in terms of } \\
\text { food security. In this review, innovative tactics and techniques for animal production are potted with } \\
\text { positive research results and their drawbacks as well. The use of innovative technologies in their respective } \\
\text { fields is close to taking control of whole world manufacturing under its hand to accomplish the world } \\
\text { prerequisite regarding food scarcity. }\end{array}$ \\
$\begin{array}{l}\text { Keywords: } \\
\text { New-age techniques } \\
\text { Food supply } \\
\text { Dustainability }\end{array}$ &
\end{tabular}

prerequisite regarding food scarcity.

wajidali.vet9@gmail.com bhatti.ahmad34@gmail.com e@asiafirdous35@gmail.com
(iD) https://orcid.org/0000-0001-5800-2031
(i) https://orcid.org/0000-0002-6590-732X
(iD) https://orcid.org/0000-0001-8901-9848

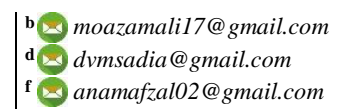

(iD) https://orcid.org/0000-0002-1454-3538

(iD) https://orcid.org/0000-0002-3551-527X

(c) $\frac{(1)(9)}{\mathrm{Er}}$ This work is licensed under Creative Commons Attribution 4.0 International License

\section{Introduction}

Globally, the human population is expected to increase more than nine billion in 2050 with a parallel accelerating rate of urbanization, more expectation and an easy lifestyle petition in the range of the same natural resources. Feeding of the accumulative population is a big challenge of the world engaging with environmental disasters like environment transformation and dispossession of nature's resources. According to the Food and Agriculture Organization (FAO, 2017) estimation, at least three billion population will enter in circle of middle-class people with increased $69 \%$ good quality food demand. The animal production is a world-leading sector to produce good quality food (protein, milk, egg) by using $80 \%$ cultivated land and $8 \%$ water of the globe. In the world, livestock products give a share of $17 \%$ calories and $33 \%$ protein consumption of total need with having both positive and destructive effects on natural assets, community vigor and fiscal progress. So the high rate of human population propagation has been generated some typical challenges for the animal production sector as continuous demand for animal products, competition for Resources, economic concerns and environmental pressure. As we know at large scale production of livestock in restricted extents has a very vast concern with farm management, environmental issues and economics of the nation (Abdalla and Lawton, 2006). The elucidation of all these challenges for boosting animal 
production comes from multifunctional educations as a very diverse arena known as new-age technology (Göncü and Güngör, 2018). The scientists and researchers have an important role in an incipient novel way to control diseases and pathogens that can abolish the livestock zone needed to meet anthropological dietary necessities. The agriculture sector is technologized as a consequence of the green revolution and helped in better management of farms in terms of land, crops, and animals through precision farming (Sundmaeker et al., 2016). New-age technology has an unconventional analytic management system through the use and combination of data sciences, software outfits, advanced sensors and system models (Dillard, 2019). As the same new-age technologies are parts of evolution in the livestock segment. Recently, in hefty enterprises, the application of innovative techniques and involuntary structure in the field of livestock production is quite necessary to attain projected performance from an animal of extraordinary inheritance (Göncü and Güngör, 2018). Manually data monitoring of livestock farm on daily basis is very challenging to attain desirable production as it is a big source of inaccuracy and work contents nevertheless it can be made easy with the use of advanced technology applications and systemic automation. Every field of animal production sector has a valuable share in the production of food for humankind and most important fields of this sector are animal reproduction, animal health management, Animal genetics, milk automation and preservation at farm level, manure management, water management, animal identification, and animal nutrition. The management and share of these all fields can be enhanced with the use of new-age techniques related to the field. Nowadays it is possible to manage a farm by using algorithms and data due to the exceptional blooming of the internet, cloud computing technology is an example as it leads to smart farming (Wolfert et al., 2017). Smart farming technology works by using hardware (utilizing drones and aerial vehicles for managing animals, crops, and land) and software (using software for data collection and processing) (Jothilakshmi et al., 2019). The farmers are using the robotic machine for managing all activities of the farm and processing of products produced by animal production units. The key technologies in livestock production are Fixed-time artificial insemination CIDR, auto-weighing, heat detection, biomarker, electronic identification, robotic milking, controlled feeding, health monitoring, and disease diagnosis sensors. (Quirino et al., 2019). These technologies are rudimentary tools to mend the animal production sector and help farmers to attain high production within the curbed area and animal of good genetic sources. In this review paper, we will try to give a trivial depiction of the practices of these new-age technologies in animal production and their benefits as well. The necessity of these new-age technologies in livestock production is very imperative because it is the very best approach to compensate for the demand of food shortage in the globe. The science is playing a significant role in the enhancement of animal life and fashioning a purity with easiness in work by the creation of new-age technologies. In the current period, some advanced countries are relying on these technologies to acquire high production from the animal sector.

\section{Use of New-Age Technologies in Animal Breeding and Genetics}

The field of animal breeding and genetics is the backbone of animal production farms and the success of the production unit. Without the use of new-age technologies, we cannot acquire apposite performance from animals of high breeding values (Göncü and Güngör, 2018). Artificial insemination is an easy and cheap process (Akin and Kara, 2019) as it is very early technical modernization in reproduction (Thibier, 2005). Now it is very common in all types of animals like swine, sheep, goat, cattle buffalo, camel and horse etc. Akin and Kara (2019) specified that turkey government recognized AI as a decent choice to improve genetic resources and animal production and give financial support to novelty of new ways. The estrous synchronization with exogenous hormonal treatment is a significant process to raise the production and prolificacy of animals. Stevenson (2001) and Abdelwahid et al. (2019) itemized different benefits of oestrus synchronization as insemination with superior bull, uniformity in calf producing and reduction in breeding season duration. Timed AI with oestrus synchronization is more suitable than natural insemination if we can control external stress to the animal. Controlled internal drug release device (CIDR) with low-level progesterone coding helpful for estrous synchronization. It has no residual side effect and very common in swine, sheep and goat (Quirino et al., 2019). In Surrogate sire technology, a male transplanted from spermatogonial stem cells of donor males can produce large numbers of progeny within the same time (Gottardo et al., 2019). Chang et al. (2003) noticed that DNA marker is very advantageous in animal breeding to foretell genetic makeup and animal performance. The development of multiple ovulation and embryo transfer (MOET) is new-age technology in the progress of animal reproduction. With the help of MOET, a user can obtain 30-50X genetic improvement on yearling females (Smith, 1988; Christensen, 1991). Genomic selection is an innovative technology in which a sample DNA can use for calculation the breeding values of animals. This technique can increase the accuracy of the selection of new breeding animals by selecting beneficial genes like milk production, disease resistance and fertility. Cappai et al. (2019) summarized that smart technologies are very dynamic for the assessment of the genotype of beef and breeding bulls. The 3D-Bull model of the Structure from Motion (SfM) algorithm is an innovative technique to evaluate animal morphology and health status. Nonstandard conceptions or else imminent abortions in dogs can diagnose by Contrast-enhanced ultrasound (CEUS). As it permits assessment of the maternal and fetal vessels in the first two-thirds of gestation deprived of any clinically pertinent inauspicious impact (Orlandi et al., 2019). Despite all these new-age technologies, the old genetic makeup is essential to the preservation of animal category and fighting against new health disasters of an animal. The freezing of old genetic germplasm of animals can store in AI straw and DNA samples in liquid nitrogen. These all innovative techniques are very mandatory to improvement of animal production by increasing output as compared to input. 


\section{Use of New-Age Technologies in Animal Reproductive Performances}

The reproduction is a key factor for the progress of any farm which always demands special care to manage it and includes some basic important factors like on-time heat detection, managing calving interval and accurate pregnancy diagnosis (PD). In different countries mostly heat detection can be done manually by visual observation while progressive innovation of new-age technologies creates modernization in the animal production field. Radio-telemetry is an automatic device which used for estrus detection in animals. Its cost is high but not more than a loss of missing an estrus cycle. Göncü and Güngör (2018) reported that estrous detection error causes a loss of 40 to 130 USD for a single cow. Pedometers are also very effective devices to detect the estrous cycle in animals by attaching it to the legs of the animal and comparing the former and current actions. According to (Chung et al., 2013), a simple microphone is also helpful to recognize the basic voice of estrous with $94 \%$ accuracy and an estrous voice is different than rest period. The teaser bull or marker are old ways to evaluate the natural process of heat in animal and these are very operative in managing basic animal reproductive performances. The pregnancy diagnosis is also a very obligatory tool for managing the reproductive performances and calving interval for farm progress. Since several centuries, the ultrasonography used for evaluation of reproductive tract and diagnosis of pregnancy in animal. Contrast-enhanced ultrasonography (CEUS) is an emerging technique for a pregnancy test and use it for assessment of fetal-maternal circulation during pregnancy in dogs of different gestation ages (Orlandi et al., 2019). Different types of immunoassays are very useful to evaluate the reproductive performance of animals monitors the progesterone level to evaluate the reproductive status of the animal (Posthuma-Trumpie et al., 2009). Ultrasonography is also very germane to monitoring the luteal size and progesterone level as these both are very important for stability of pregnancy (Rocha et al., 2019). ELISA is a very famous new-age technology which is useful for determining the reproductive performances in the animal production sector. Sandwich ELISA can use for prolactin detection in domestic birds and prolactin is a very important hormone for broodiness and reproductive performances (Chen et al., 2019). Radiotelemetry is also a beneficial tool for the animal production sector to minimize the manual procedures. Weatherhead and Blouin-Demers (2004) proposed a study of radiotelemetry to assess the effect of reproduction and survival of black rat snakes (Elaphe obsoleta) by using data of 6-years. These all types of new-age techniques are maintaining the balance between time and accuracy to get more performances of animals and the success of the farm.

\section{Use of New-Age Technologies in Animal Health Observation}

Currently, due to the adaptation of innovative techniques in the animal production sector, there has been an inverse relationship between the number of animals per farm and the number of farms whereas a direct relation with production complications has reported (Thornton, 2010). All these problems in the animal health sector can be sorted out with the application of new-age technologies resulted from multidisciplinary findings. In the 1980's the automation of livestock farms (milking, health and management) leads to high economic benefits by reducing human errors on medium to large scales farms (Ipema et al., 2012). With innovation in technology, the work load on farmers has reduced and enhanced animal productivity significantly (Göncü and Güngör, 2018). Radiofrequency identification (RIFD) is an emergent tool used to tracking animals especially the missing ones and evaluating vaccination schedules regularly. Thermal imaging is creating a dynamic change in the livelihood of farm animals by sensing underlying injuries and pre-clinical stages of different diseases. Moreover, thermal imaging helps us to detect ailments in vicious farms and wild animals from a safer distance without getting themselves injured. On-time detection of early stages of diseases like mastitis, inflammation, and lameness will help out in reducing economic losses in veterinary medical services Thermal imaging also helps to find the stray lambs and calves even in darkest conditions. Commercial cattle farming has become a lucrative industry, but monitoring animal health is still a major concern. To cover up health issues a wireless health checking system has been developed through which the ruminant biological factors like temperature, urine $\mathrm{pH}$ value and wounds can be detected. Collectively this system is (WBSN) wireless body sensing network and it works with emergency alarms attached with body sensors upon detecting any dramatic change in the biological parameters. The RGB sensors detect changes during initial stages of a wound through color change whereas in coordination with temperature sensors these RGB sensors help to detect FMD in herds (Jegadeesan and Venkatesan, 2016). Remote rumen temperature checking has used as a prospective tool for early identification of diseases in beef cattle. The 24 Angus breed cattle showed a significant correlation between the change in rectal temperature and rumen bolus temperature when exposed to bovine viral diarrhea virus (BVDV) and BRD pathogen. Average findings showed only $0.13^{\circ} \mathrm{C}$ difference in both temperatures. Thus rumen bolus temperature can be used as a potent source in the detection of adverse health measures in cattle (Rose-Dye et al., 2011). The establishment of biomarkers is of immense importance as changes in the biomarker profile is directly linked with clinical changes in the animal body due to disease causative agent. Furthermore, innovation in the biomarker technique is the induction of post-genome technology that act precisely on specific biomarker in a pool of molecules inside a tissue or fluid. The development of omics (transcriptomics, proteomics, and metabolomics) is a remarkable discovery in the biomarker field to assess animal health and disease ailment (Moore et al., 2007). Current methods of animal health monitoring systems are inadequate as they provide sparse information and high veterinary medical services to reduce the disease pressure. A prototype telemonitoring setup has developed that delivers constant data regarding animal health. Meat 
consumers from all over the world demanded checks and balances of meat suppliers especially for diseases like anthrax, FMD, mad cow and other diseases, thus livestock tracking will be compulsory soon. This telemonitoring wearable prototype system is accomplished to organize a variety of parameters including environmental (temperature \& humidity), biological (temperature, heart rate) and motion of animals like GPS location and tracking (Smith et al., 2006).

\section{Use of New-Age Technologies in Animal Farm Management (Water, Manure and Automatic Machinery)}

Proper farm management is essential for attaining high economic goals by controlling each factor involved in farm productivity. Water and manure management is very important as water is directly associated with animal's health while the dung produced by animals has adverse impacts on the community health. Many techniques have been adopted to recycle the water used by animals to overcome the issues of water scarcity. Dairy farm effluent is composed of $99 \%$ of water and only $1 \%$ of solids, removing these colloidal solids water can recycled or farm requirements. A pilot study in New Zealand suggested that by using coagulants the turbidity of water was reduced up to $97 \%$ and $99.99 \%$ removal of E.coli in comparison to untreated dairy effluent. Furthermore, no harsh effect of treated FDE recorded on land application of that water (Cameron and Di, 2019). With an increasing number of animals, the dung produced by animals is also significantly swelling. To cope up the animal manure is always had been challenging because farmers did not have enough knowledge to properly store and dispose of the animal dung. Traditional methods included the heaps' formation, pads, and vessels for urine. Nitrogen is the key element monitored as a source of fertilizer. Manure produced will be solid or in a liquid state as liquid manure is mixed up with water used for irrigation purposes whereas the solid manure used for biogas and energy generation process by helping the emission of methane in the atmosphere that is a major factor for the greenhouse effect. A recent study suggested that effective processing of poultry manure can be used to breakdown the plastic material (Okoh and Atuanya, 2014). The bad odor produced by animal dung is a serious concern for people dealing with animals on farms. Changes in the diet plan also helpful in gas emission from animal gut (Van Horn et al., 1994). Animals dung can also be converted to oil products by thermochemical conversion techniques (He et al., 2000). Improved solid to liquid separation methods is now allowing up to $90 \%$ removal of solids from raw manure (Vanotti et al., 2002). Another technique is established to convert the dung into appreciated larval biomass with the continuous digestion process of insects especially the black soldier fly (Sheppard et al., 2002). Scientist has developed several modern tools to enhance the productivity of farm animals. Modern tools includes the automatic milking systems, sensors for heat detection, sensors for health monitoring as well as sensors for feeding. MS-R1 and MS-D1 are robots invented by Boumatic Company. Robots work by identifying the cow and governs either it's time for milking or not and also regulate the concentrate quantity. Robotic calf feeders lessen the labor pressure and efficiently monitor the calf health. It also capable of heating the water unit, mixing the milk replacer with water. Ruminal $\mathrm{pH}$ and temperature can be detected continuously by a sensor named Smaxtec $\mathrm{pH}$ and temp sensor. Delaval has developed Del Pro a body conditioning score sensor it notifies the recommended score. Another gadget named DCC helps in counting the somatic cells by staining nuclei by DNA specific fluorescent reagent. Temp Verified fever Tags are used to monitor the core body temperature every 15 minutes. These sensors are easy to use as they are placed in an animal's ear canal and alarms by a red flashing light. (Horizon 2020 EU funding for research and innovation).

\section{Use of New-Age Technologies in Animal Milking Automation}

In the field of animal dairy production, milk is a very important output for the success of a farm. It is very obligatory to get maximum milk with healthful procedures of animals and consumers. The new-age technologies have been developed for proper milk automation and caring for animal health. This is involving in animal production before the 1990s and demands distinctive management which assures the animal health and purity of milk. To avoid the manual error robotic milking with a multifunctional sensor has equipped. These sensors are helpful to identify the milk problems and calculation of milk contents (Göncü and Güngör, 2018). Automatic milking parlor with post and pre milking disinfectant dipping and milk calculating sensors are very common in developed countries like the USA, Canada, Australia, etc. Das et al. (2019) stated that Cloud Computing associated milking automation and robotic feeding is very common in young farmers of Ireland. Automatic milking systems (AMS) are very common at dairy farms of the UK to condense the labor cost and human-animal interactions (Holloway et al., 2014). Simple automatic cup removal devices are also new techniques to monitor the milk flow and automatic removal of cups from teat on the base of pressure. These cups have disinfectant solutions to prevent mastitis and sensor for checking milk connectivity. Electronic separation gates and daily behavior monitoring sensors also attached to the milk automation system. These support in evaluating the usual health of animal and automatic opening of gates before and after milking. Separation gates can receive a signal for opening and closing at the time of milking end to remove the labor cost to manage the animal in different groups. This separation gate technology is not common in every country but now it is getting the huge interest of young farmers on the base of collective benefits for large herds. Now in these days, PD sensors attached with an automatic milking parlor for pregnancy diagnosis by evaluating the level of progesterone in milk. The automatic milking system (AMS) provides more benefits and profit as compared to obsolete milking (Sauer and Zilberman, 2012) as it offers distinct ways to promise food security and safe animal's body condition, hazards of lameness and udder infections (De Koning, 2010). These all types of new-age technologies are very mandatory for maintain high yield of any herds and raise the share in the national economy of the animal production sector. 


\section{Use of New-Age Technologies in Animal Electronic Identification}

The animal identification is very compulsory to analyze the activities of animals that directly predict an animal's health status and progress of any animal production unit. The suggested solution of tracing animals is the distinctive identification of every animal throughout its lifetime, by using an electronic identifier (Ribó et al., 2001). The system permits the automation of the farm management system with decreased labor costs. Electronic identification can be utilized for the meat supply chain to process data access automatically to national registry databases and abattoirs (Barge et al., 2013). Its Results were invigorating for identification of calves both in slaughterhouses and farms, while in swine breeding, identification was censorious for small piglets (Barge et al., 2013).Radio Frequency Identification (RFID) is getting globally acknowledge as the technology to perform animal identification, and has become an important form of livestock management in many countries (such as Canada and Australia), as well as in the European Union, while other countries have started trials of the technology (Vlad et al., 2012). The instrumental an RIFD and 3D assessment of bull morphology of the Charolais breed in an entirely digital 3D image successfully represents the morphology of the live animal (Cappai et al., 2019). Liu et al. (2019) summarized that pig marketing as transportation, slaughtering and loading can control by the use of RFID and sensor technology. The trolley identification is also famous as a trolley identification reader is given besides the trail to automatically reading each one of the trolley identification numbers and inputting the information into a computer (Knosby, 1986). This is a total "traceback' system for the identification of each animal from birth through the animal's slaughter. The electronic ear tag is capable of reading a radio frequency identification device (RFID), storing that data in a processing unit in the ear tag, and then transmitting data to a Satellite, which relays the information of an individual animal to a hub server (Gray, 2005). A user may trace animal location, behavior, health, and other information at a base station monitor or a remote wireless device in communication with the base station and plurality of tags (Mobley, 2019). Williams et al. (2019) analyzed the aptitude of Radio Frequency Identification (RFID) reader data from remote weighing technology to access cattle visit times and time intervals between cattle visits to water points and explained that RFID reader data is capable to identify behavioral variations in proportion to water accessibility and climate and is an appropriate tool to study cattle water point utilization. These identification system tracks animals from their birth until their slaughter, monitoring every single parameter or element that could be of interest: nutrition, health history, behavior, milk/wool production, potentially non-ordinary situations such as theft and loss (Voulodimos et al., 2010).

\section{Uses of New-Age Technologies in Animal Nutrition and Feeding}

The nutrition and feeding is a core class of animal production units and all approaches are very cooperative to intensification the products and success of the firm.
Automatic weaning based on solid feed intake according to the weight of calves is an automatic process to increase consumption of starter (Khan et al., 2016) and decline hunger of calves (De Passillé et al., 2011; Benetton et al., 2019). Ruminating duration is a crucial index of the health of ruminants (Stangaferro et al., 2016). Unhealthy animals ruminate less, so the assessment of the rumination time gives information about health status. Utilizing microphones, $\mathrm{pH}$ boluses accelerometers and laser interferome try is very popular (Zin et al., 2016). To indicate rumination spans with $86.1 \%$ overall accuracy Support Vector Machine (SVM) has been utilized with reticuloruminal motion energy and the time between reticuloruminal contractions as inputs, confirmed through neck mounted rumination collars (Hamilton et al., 2019). In dairy cattle, Near infra-red (NIR) technology could be utilized at farm level in a precision feeding system in an economically sustainable manner to provide daily nutrients with less metabolic alterations and high efficiency of utilization of feed protein (Cappai et al., 2019). A broad extent of metabolites that have been associated to boost or reduce gut health produced by composite microbial ecosystems occupying the GIT of farm animals (Verbeke et al., 2015; Celi et al., 2019). An archive of plausible gut health biomarkers has been created for utilization in pigs and poultry (Niewold, 2015; Gilani et al., 2016; Celi et al., 2019). Advanced computer software and commercial formulation databases commercial aqua-feed depending on key limiting nutrients are very common in the aquaculture industry (Turchini et al., 2019). A prototype for fermentation and storage systems of TMR feed for cattle is formed to improve animal production (Woo et al., 2019). Computerized programs with the software are accessible in the market for feeding according to age, the weight of animal, lactation stage and purpose of farming. These programs are equally functional for the preparation of feeds for demand of animal production units as controlled poultry and dairy farms are very reliable on this new-age technology. Electronic Concentrate Feeding system, Computer-controlled calf feeders, and rumen activity sensors are very useable on large scale dairy farms as they provide complete satisfied result of accurate feeding and animal health. Göncü and Güngör (2018) itemized that these automatic systems simply consist of a control panel, command manager, a scale and appropriately organize apparatus for feeding of different groups of animals.

\section{Use of New-Age Technologies in Environment Control of Livestock Farm}

The environment is the very foremost factor of any animal production unit as animal's performance greatly affected by the surrounding environment. The stress of the surrounding environment to any animal can cause serious results in the form of a decrease in production, mortality and economic losses of that unit. Environmental control in confined production units of animals like controlled poultry and dairy farms is very obligatory. Chief factors of the surrounding environment affecting animal production are temperature, humidity, wind pressure, light intensity, ammonia \& carbon dioxide, etc. On the base of the sensitivity of animals to stress of these factors, the present world has developed a series of environment control 
sensors. Innovative sensors with the analytical unit are responsible for gather data and its analysis to develop a convenient systemical operation for maintaining the thermoneutral or comfort zone of an animal.Göncü and Güngör (2018) identified that thermoneutral zone range of cattle is between -5 to $25^{\circ} \mathrm{C}$ while new-age technology helps to maintain this range and control all types of stress generated from different environmental factors. The temperature sensor feeds to an automatic control system for managing the internal temperature of a production unit with the help of fans and pads. All kinds of gases like ammonia \& $\mathrm{CO}_{2}$ can sense with their relevant sensors and operated to eradicate out from shed for a decline of animal stress. Wind and brightness sensors also premeditated to regulate the wind pressure and brightness of shed with assistance of Curtin and roof of production unit according to the need of animal desire and optimal production. These sensors directly connected to the automatic data analysis system and the controller adjusts the production unit according to need. According to Fournel et al. (2017), environmental control of shed depend on the heat \& moisture production rate of the shed and measured between $1950 \& 1980$. Old all approaches to controls the environmental hassle of animals were incompetent, so that's why this is very essential to depend on new-age technologies for getting prime production of animals for the necessity of growing population.

\section{Conclusion}

The rapid increase in human population is generating immense pressure on the animal production sector to fulfill the demand and supply of foodstuff, the best option to restrain this pressure is the adoption of new-age techniques in animal production sector. Large scale farming in advance countries is completely reliant on innovative techniques to get prime consequences. These technologies are obliging to escalate the productivity of animal production sector in order to boost up economy and sophistication of work. All the latest technologies are not common in the market but new farmers are preferring to adopt innovative methods of animal farming. So within a short period, the animal production sector will be reliable on these new-age techniques to accomplish optimal production level.

\section{References}

Abdalla CW, Lawton JL. 2006. Environmental issues in animal agriculture. Choices, 21: 177-182.

Abdelwahid HH, Abdallah AA, Mohammed RM, Shulukh ESA, Habib AB. 2019. Effects of Timed Artificial Insemination Following Oestrous Synchronization on Pregnancy Rate of Dairy Cattle in the tropics. Int. J. of Multidisciplinary and Current research, 7 .

Akin S, Kara A. 2019. Factors affecting the farmers'decision on artificial insemination: a case study of diyarbakir province, turkey. Appl Ecol Environ Res, 17: 1389-1399.

Barge P, Gay P.Merlino V. Tortia C. 2013. Radio frequency identification technologies for livestock management and meat supply chain traceability. Can. J. Anim. Sci., 93: 23-33.

Benetton J, Neave H, Costa J, von Keyserlingk M, Weary D. 2019. Automatic weaning based on individual solid feed intake: Effects on behavior and performance of dairy calves. J Dairy Sci, 102: 5475-5491.
Cameron KC, Di HJ. 2019. A new method to treat farm dairy effluent to produce clarified water for recycling and to reduce environmental risks from the land application of effluent. $\mathbf{J}$ Soils Sed, 19: 2290-2302.

Cappai MG, Gambella F, Piccirilli D, Rubiu NG, Dimauro C, Pazzona AL, Pinna W. 2019. Integrating the RFID identification system for Charolaise breeding bulls with 3D imaging for virtual archive creation. PeerJ Computer Science, 5: e179.

Celi P, Verlhac V, Calvo EP, Schmeisser J, Kluenter AM. 2019. Biomarkers of gastrointestinal functionality in animal nutrition and health. Anim Feed Sci Technol, 250: 9-31.

Chang K, Beuzen N, Hall A. 2003. Identification of microsatellites in expressed muscle genes: assessment of a desmin (CT) dinucleotide repeat as a marker for meat quality. The Vet. Journal, 165: 157-163.

Chen R, Guo R, Zhu H, Shi Z. 2019. Development of a sandwich ELISA for determining plasma prolactin concentration in domestic birds. Domest Anim Endocrinol, 67: 21-27.

Christensen LG. 1991. Use of embryo transfer in future cattle breeding schemes. Theriogenology, 35: 141-149.

Chung Y, Oh S, Lee J, Park D, Chang HH, Kim S. 2013. Automatic detection and recognition of pig wasting diseases using sound data in audio surveillance systems. Sensors, 13: 12929-12942.

Das V, Sharma S, Kaushik A. 2019. Views of Irish Farmers on Smart Farming Technologies: An Observational Study. AgriEngineering, 1: 164-187.

De Koning C. 2010. Automatic milking-common practice on dairy farms.

De Passillé A, Borderas T, Rushen J. 2011. Weaning age of calves fed a high milk allowance by automated feeders: Effects on feed, water, and energy intake, behavioral signs of hunger, and weight gains. J Dairy Sci, 94: 1401-1408.

Dillard HR. 2019. Global food and nutrition security: from challenges to solutions. Food Security, 11: 249-252.

FAOSTAT 2017. Statistical data. Food and Agriculture Organization of the United Nations, Rome, Italy http://www.fao.org/faostat/en/\#data/QA access: 12.05.2019.

Fournel S, Rousseau AN, Laberge B. 2017. Rethinking environment control strategy of confined animal housing systems through precision livestock farming. Biosys Eng, 155: 96-123.

Gilani S, Howarth GS, Kitessa SM, Forder RE, Tran CD, Hughes RJ. 2016. New biomarkers for intestinal permeability induced by lipopolysaccharide in chickens. Ani Production Sci, 56: 1984-1997.

Göncü S, Güngör C. 2018. The Innovative Techniques in Animal Husbandry. Ani Husbandry and Nut: 1.

Gottardo P, Gorjanc G, Battagin M, Gaynor RC, Jenko J, RosFreixedes R, Whitelaw CBA, Mileham AJ, Herring WO, Hickey JM. 2019. A strategy to exploit surrogate sire technology in livestock breeding programs. G3: Genes, Genomes, Genetics, 9: 203-215.

Gray J. 2005. Asset management of livestock in an open range using satellite communications. Google Patents.

Hamilton AW, Davison C, Tachtatzis C, Andonovic I, Michie C, Ferguson HJ, Somerville L, Jonsson NN. 2019. Identification of the rumination in cattle using support vector machines with motion-sensitive bolus sensors. Sensors, 19: 1165.

He B, Zhang Y, Funk T, Riskowski G, Yin Y. 2000. Thermochemical conversion of swine manure: an alternative process for waste treatment and renewable energy production. Trans ASAE, 43: 1827.

Holloway L, Bear C, Wilkinson K. 2014. Robotic milking technologies and renegotiating situated ethical relationships on UK dairy farms. Agr Human Values, 31: 185-199.

Ipema A, Holster H, Hogewerf P, Bleumer E. 2012. Towards an open development environment for recording and analysis of dairy farm data. 
Jegadeesan S, Venkatesan GP. 2016. Smart cow health monitoring, farm environmental monitoring and control system using wireless sensor networks. Int $\mathbf{J}$ Adv Engg Tec,7(1): 334: 339.

Jothilakshmi P, Mohanasundaram R, Iniyavan D, Jithin S. 2019. Design and Fabrication of $5.8 \mathrm{GHz}$ ISM Band Microstrip Patch Antenna Through Aperture Coupled Feeding Technique. International Journal of Emerging Technologies and Innovative Research, ISSN: 2349-5162.

Khan S, Ullah M.W, Siddique R, Nabi G, Manan S, Yousaf M, Hou H. 2016. Role of recombinant DNA technology to improve life. Int journal of genomics, 2016.

Knosby AT. 1986. Livestock identification system. Google Patents.

Liu H, Yao Z, Zhou W, Zhao FT. 2019. Research on Pig Transportation Management System Model Based on RFID and Sensor Technology. Available at SSRN 3319659.

Mobley T. 2019. Tracking and monitoring of animals with combined wireless technology and geo-fencing. Google Patents.

Moore RE, Kirwan J, Doherty MK, Whitfield PD. 2007. Biomarker discovery in animal health and disease: the application of post-genomic technologies. Biomarker insights, 2: 117727190700200040.

Niewold T. 2015. Chapter 9: Intestinal health biomarkers in vivo. In: Intestinal health: Key to maximise growth performance in livestock. Wageningen Academic Publishers. pp: 717-721.

Okoh E, Atuanya E. 2014. Impacts of soil composting and poultry manure on biodegradation of polyethylene. Int. J. Appl. Microbiol. Biotech. Res, 2: 18-29.

Orlandi R, Vallesi E, Boiti C, Polisca A, Troisi A, Righi C, Bargellini P. 2019. Contrast-enhanced ultrasonography of maternal and fetal blood flows in pregnant bitches. Theriogenology, 125: 129-134.

Posthuma-Trumpie G.A, van Amerongen A, Korf J, van Berkel W.J. 2009. Perspectives for on-site monitoring of progesterone. Trends Biotechnol, 27: 652-660.

Quirino M, Pinheiro ARA, Santos JT, d.Ulguim RDR, Mellagi APG, Bortolozzo FP. 2019. Reproductive performance of fixed-time artificial insemination in swine and factors for the technology success. Cienc. Rural, 49.

Ribó O, Korn C, Meloni U, Cropper M, De Winne P, Cuypers M. 2001. IDEA: a large-scale project on electronic identification of livestock. Revue Scientifique et Technique-Office International des Epizooties, 20: 426-436.

Rocha CC, Martins T, Cardoso BO, Silva LA, Binelli M, Pugliesi G. 2019. Ultrasonography-accessed luteal size endpoint that most closely associates with circulating progesterone during the estrous cycle and early pregnancy in beef cows. Anim Reprod Sci, 201: 12-21.

Rose-Dye T, Burciaga-Robles L, Krehbiel C, Step D, Fulton R, Confer A, Richards C. 2011. Rumen temperature change monitored with remote rumen temperature boluses after challenges with bovine viral diarrhea virus and Mannheimia haemolytica. J Anim Sci, 89: 1193-1200.

Sauer J, Zilberman D. 2012. Sequential technology implementation, network externalities, and risk: the case of automatic milking systems. Agr Econ, 43: 233-252.

Sheppard DC, Tomberlin JK, Joyce JA, Kiser BC, Sumner SM. 2002. Rearing methods for the black soldier fly (Diptera: Stratiomyidae). J Med Entomol, 39: 695-698.

Smith C. 1988. Applications of embryo transfer in animal breeding. Theriogenology, 29: 203-212.
Smith K, Martinez A, Craddolph R, Erickson H, Andresen D, Warren S. 2006. An integrated cattle health monitoring system. In: 2006 International Conference of the IEEE Engineering in Medicine and Biology Society. IEEE. pp: 4659-4662.

Stangaferro M, Wijma R, Caixeta L, Al-Abri M, Giordano J. 2016. Use of rumination and activity monitoring for the identification of dairy cows with health disorders: Part I. Metabolic and digestive disorders. J Dairy Sci, 99: 73957410.

Stevenson JS. 2001. Reproductive management of dairy cows in high milk-producing herds. J Dairy Sci, 84: E128-E143.

Sundmaeker H, Verdouw C, Wolfert S, Pérez Freire L. 2016. Internet of food and farm 2020. Digitising the IndustryInternet of Things connecting physical, digital and virtual worlds. Ed: Vermesan, O, \& Friess, P: 129-151.

Thibier M. 2005. The zootechnical applications of biotechnology in animal reproduction: current methods and perspectives. Reprod Nutr Dev, 45: 235-242.

Thornton PK. 2010. Livestock production: recent trends, future prospects. Philosophical Transactions of the Royal Society B: Biological Sciences, 365: 2853-2867.

Turchini GM, Trushenski JT, Glencross BD. 2019. Thoughts for the future of aquaculture nutrition: realigning perspectives to reflect contemporary issues related to judicious use of marine resources in aquafeeds. N Am J Aquacult, 81: 13-39.

Van Horn H, Wilkie A, Powers W, Nordstedt R. 1994. Components of dairy manure management systems. J Dairy Sci, 77: 2008-2030.

Vanotti M, Rashash D, Hunt P. 2002. Solid-liquid separation of flushed swine manure with PAM: effect of wastewater strength. Trans ASAE, 45: 1959.

Verbeke KA, Boobis AR, Chiodini A, Edwards CA, Franck A, Kleerebezem M, Nauta A, Raes J, Van Tol EA, Tuohy KM. 2015. Towards microbial fermentation metabolites as markers for health benefits of prebiotics. Nutr Res Rev, 28: 42-66.

Vlad M, Parvulet RA, Vlad MS. 2012. A survey of livestock identification systems. In: Proceedings of the 13th WSEAS International Conference on Automation and Information, (ICAI12). pp: 165-170.

Voulodimos AS, Patrikakis CZ, Sideridis AB, Ntafis VA, Xylouri EM. 2010. A complete farm management system based on animal identification using RFID technology. Comput Electron Agric, 70: 380-388.

Weatherhead PJ, Blouin-Demers G. 2004. Long-term effects of radiotelemetry on black ratsnakes. Wildl Soc Bull, 32: 900906.

Williams LR, Fox DR, Bishop-Hurley GJ, Swain DL. 2019. Use of radio frequency identification (RFID) technology to record grazing beef cattle water point use. Comput Electron Agric, 156: 193-202.

Wolfert S, Ge L, Verdouw C, Bogaardt MJ. 2017. Big data in smart farming-a review. Agricultural Systems, 153: 69-80.

Woo SM, Uyeh DD, Kim J, Hong DH, Park T, Ha YS. 2019. A study on the optimal fermentation conditions for mixed byproducts in livestock feed production. Eng in Agri, Envir and Food.

Zin TT, Kai H, Sumi K, Kobayashi I, Hama H. 2016. Estrus Detection for Dairy Cow Using a Laser Range Sensor. In: 2016 Third International Conference on Computing Measurement Control and Sensor Network (CMCSN). IEEE. pp: 162-165. 